\title{
6
}

\section{Work habits and localised authority in Anmatjere CDEPs: Losing good practice through policy and program review}

\author{
Will Sanders
}

\section{Introduction}

In 2004, as part of an Indigenous community governance project, I began attending monthly meetings of the Anmatjere Community Government Council (ACGC) two or three times per year. ACGC was not an Indigenous community organisation. It was a general remotearea local government, but its constituency and elected membership were about 90 per cent Indigenous. ACGC in 2004 did not administer a Community Development Employment Projects (CDEP) scheme, but there were three CDEP providers in its area, two at the southern outlying settlements of Laramba and Engawala and one in the north at Wilora. In the geographic centre of ACGC's operations around Ti Tree there was no CDEP (see Fig. 6.1). The unemployed in this central area received Newstart Allowance from Centrelink, as did the unemployed elsewhere in Anmatjere if positions on CDEP were not available. In 2006, as a result of the Department of Employment and Workplace Relations' (DEWR) contested contractualism (see Chapter 2), these arrangements for the provision of CDEP in the Anmatjere region began to change. ACGC was encouraged to apply to become a new 
CDEP provider in Ti Tree, Nturiya, Alyuen and Pmara Jutunta. In this they were successful. However, DEWR also asked ACGC to take on the existing CDEPs in Laramba and Engawala, which DEWR regarded as too small and not well administered. ACGC agreed, somewhat reluctantly, knowing that this would be viewed unfavourably in Laramba and Engawala as a Ti Tree takeover. Thus began my involvement with Anmatjere CDEPs, first assisting a governance consultant over a couple of months and then over the longer term as a researcher who kept turning up at local government meetings.

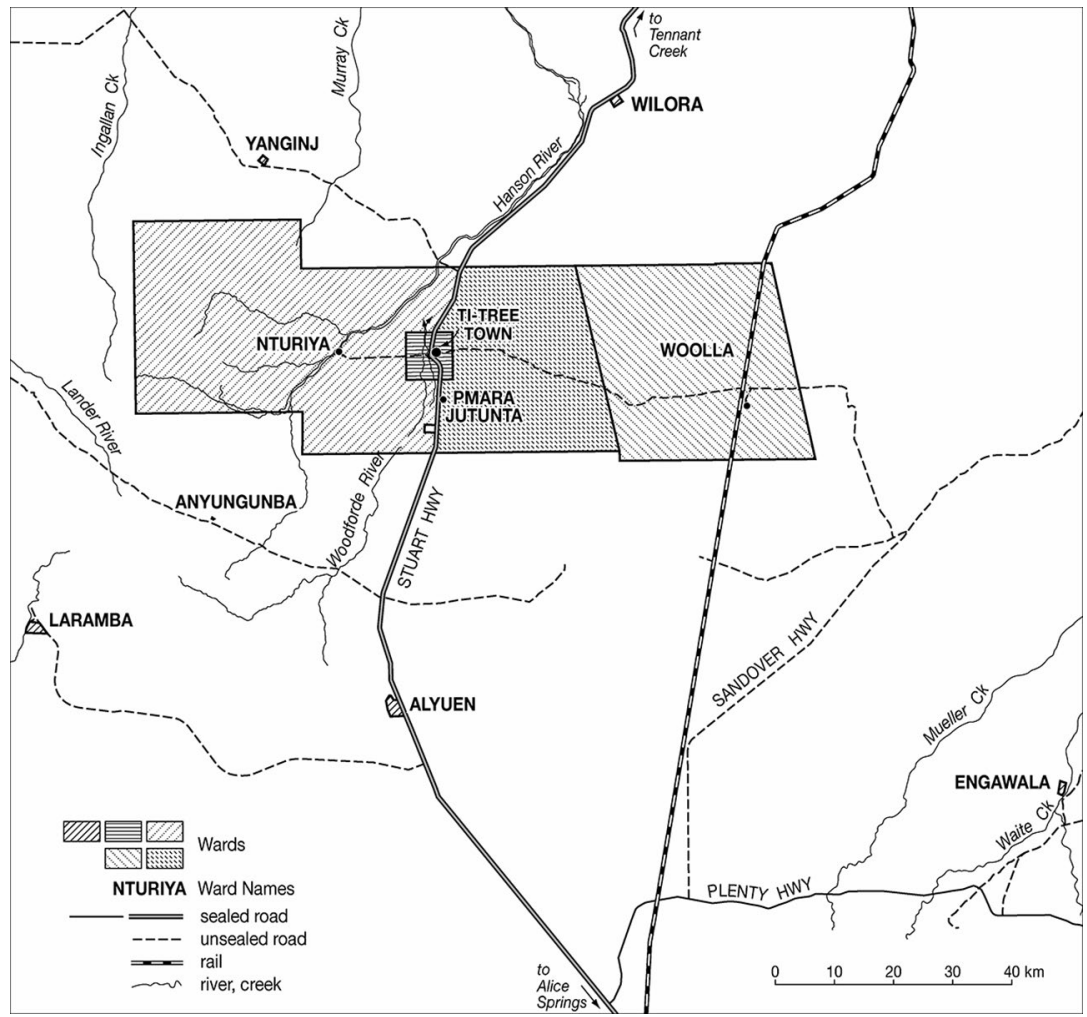

Fig. 6.1 Wards of Anmatjere Community Government Council

Notes: ACGC's main office, works yard and chambers were in Ti Tree town, one of 10 wards that were each allowed two elected council members. Three large surrounding wards covered the Ahakeye Land Trust, Aboriginal-owned land that had previously been the pastoral lease know as Ti Tree Station. The six tiny outlying wards were Aboriginal community living area excisions from surrounding pastoral leases. These pastoral leases and their residents were not included in ACGC. Neither was a small rectangle of horticultural land to the southwest of Pmara Jutunta. ACGC thus combined nine wards based on Aboriginal community living areas and land with one open-town ward.

Source: CartoGIS, College of Asia and the Pacific, The Australian National University. 
In the following analysis, I emphasise the highly localised authority structures of Anmatjere CDEPs and the work habits of participants as these developed from 2006 to 2013. This period includes the amalgamation of ACGC in 2008 into the much larger Central Desert Shire. The new Shire became the CDEP provider in five other settlements outside the Anmatjere region. My observation of CDEP in the Shire expanded to one of these settlements to the east, but not to those in Warlpiri country to the west. My analysis also covers the closure of CDEP in 2013 and the transition to the Remote Jobs and Communities Program (RJCP) over the next year or two. It is this latter period that gives this chapter its subtitle and argumentative theme- that good practice was lost through the processes of policy and program review that led to RJCP. This should not be taken as a critique of all policy and program review, but it should alert us to the potential for such processes to have negative, as well as positive, consequences. I will return to this argument about the relationship between policy review and practice in a later section of the chapter, but first I tell the story of Anmatjere CDEPs as I observed them from 2006 to 2013.

\section{Governance work in Laramba and Engawala}

When DEWR announced that ACGC was to become the new CDEP provider in Laramba and Engawala in mid-2006, ACGC wisely sought help from a governance consultant to manage the transition process. Rob, from the Alice Springs firm Burdon-Torzillo, convened meetings at Laramba and Engawala and I became his assistant. The purpose of the meetings was to clarify understandings among CDEP participants and community leaders about how the new arrangements for CDEP would work. CDEP participants would have to change to become ACGC employees, but there were many other aspects of the existing CDEP arrangements that ACGC wanted to preserve, such as basic daily work routines and access to local work spaces and equipment. Rob explained, on behalf of ACGC, what needed to change and what existing arrangements in Laramba and Engawala could remain. CDEP teams would still assemble and work under local supervision in local work spaces in the two communities using local equipment. Written agreements to this effect were drawn up and signed, but the process of doing so was of more importance than the later existence of the documents, which quickly faded from view. 
Rob was a very experienced operator who handled with skill two very different meeting styles at Laramba and Engawala, one a small meeting of community leaders around a table, and the other an openair, gender-divided mass community meeting. He also dealt well with ACGC's central administration in Ti Tree, explaining how he thought local autonomy in Laramba and Engawala could be respected while also creating some sense of one regional Anmatjere CDEP. Rob's work, together with my assistance, also reinforced some ideas the ACGC central administration had about how to set up the new CDEP in the area around Ti Tree (see Fig. 6.1). Primary among these ideas was having CDEP offices at Pmara Jutunta and Nturiya within easy walking distance of the houses of participants.

\section{CDEP offices in Pmara Jutunta and Nturiya}

Reconditioning an old community office at Pmara Jutunta became the first task for CDEP participants in that community. They assembled there four mornings per week to assist other ACGC staff with the work and the renovated office then became their daily meeting place. There was an equipment enclosure created on the verandah on one side of the building from which the male team of CDEP participants would take out whipper snippers and other equipment to undertake landscape maintenance around the community and adjacent cemetery. Art equipment was also available and often led to small groups of participants working along the verandah, mainly women but sometimes also men. Inside there was office work, such as answering the phone and filling in forms. The Pmara Jutunta CDEP participants seemed proud in 2006 and 2007 to be part of getting their community office up and running again after some years of closure (see Fig. 6.2). 


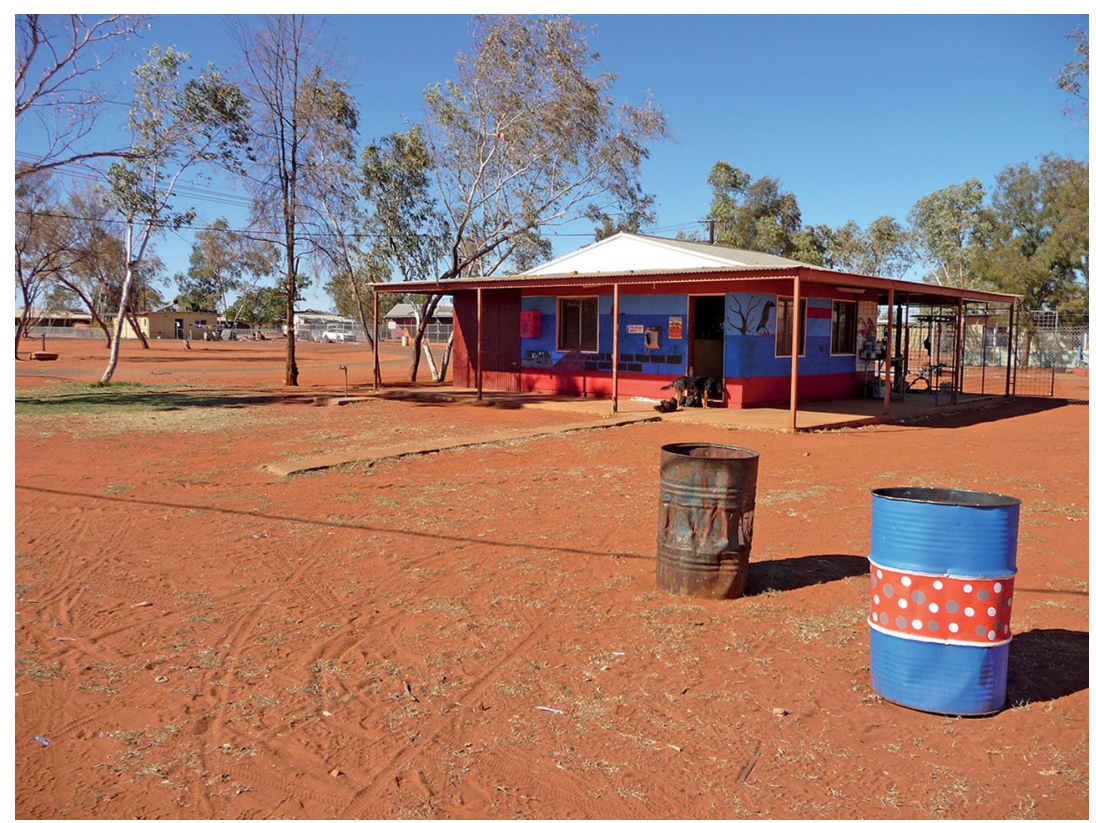

Fig. 6.2 Pmara Jutunta CDEP Office 2008

Source: Photograph taken by author.

At Nturiya, an unoccupied house was identified for conversion to a CDEP office. This never had quite the sense of being a community office, as in Pmara Jutunta, but it was the place where CDEP participants in Nturiya were expected to turn up four mornings per week. A produce garden was developed in the yard around the house and much time and energy went into gently tending and watering it. Inside was a desk, a phone and a changing array of notices. Some informal signs painted on exterior walls suggested the localised nature of authority (see Fig. 6.3).

What these two CDEP offices established, in Pmara Jutunta and Nturiya, was a physical infrastructure of daily work and localised authority. They provided a place for CDEP participants to turn up four mornings per week and have their attendance noted by supervisors and managers. They also provided a place for storage and access to equipment associated with CDEP activities, like gardening, landscape maintenance and art. This emulated the existing arrangements at Engawala and Laramba, which both had community offices and equipment/activity spaces where CDEP participants would turn up four mornings per week. 


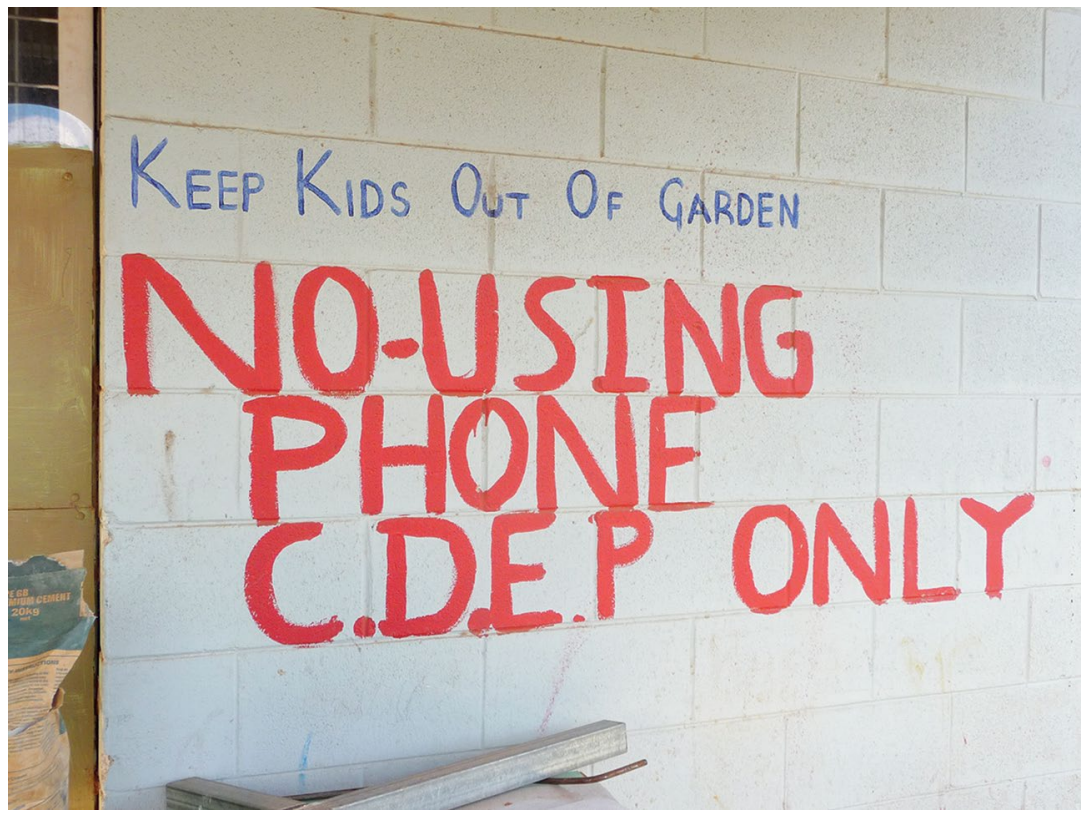

Fig. 6.3 Nturiya CDEP Office signs

Source: Photograph taken by author.

\section{Horticulture and a men's shed: Activities at Pmara Jutunta and elsewhere}

During 2007, CDEP activities at Pmara Jutunta were substantial. An area of grape farms to the southwest of Pmara Jutunta, dating back to the 1960s, provided winter pruning work for CDEP participants and a chance to earn 'top-up'. An adjacent horticultural research station owned by the Northern Territory government also became involved in supervising these CDEP participants and providing them with a certificate course in horticulture. These activities took the Pmara Jutunta CDEP participants out of their community, but the office in the settlement was still the meeting place at which they would assemble four mornings per week and from which they would be transported elsewhere to activities.

Another development during this time was that the male CDEP participants developed the idea of recladding the frame of an old mechanic's shed over the road from the community office in Pmara 
Jutunta. There was enough money in the CDEP budget to buy the materials and over a six-month period, with some technical help from the organisation 'Indigenous Community Volunteers', the shed was restored to a reasonable level of safety and workability. This allowed the male CDEP workers to assemble at the shed each morning, rather than at the community office, which became more the women's domain.

By comparison with this level of activity at Pmara Jutunta, Nturiya struggled to keep its CDEP participants occupied. The only link outside the settlement on which they seemed able to draw for activities was a community-owned pastoral operation, which very occasionally called on their labour. Just turning up at the office four mornings per week wore a little thin, as there was only so much watering of the grass and tending to the produce garden that eight to 10 participants could do. At Pmara Jutunta, the infrastructure of localised authority and daily work habits was operating well, whereas at Nturiya it was more minimal. Though I visited Laramba and Engawala less during 2007-08, I heard reports that daily work routines and activities were working well in the former, but more minimal and variable in the latter.

The CDEP at Wilora in the north of Anmatjere presented another model again. It had not become part of ACGC's CDEP in 2006, but had continued to be run as a southern outpost of a Barkly regional CDEP further to the north. With no office in the settlement, Wilora CDEP struggled to maintain a work routine of turning up four mornings per week for activities. But CDEP in Wilora did appear to be a useful mechanism for organising bursts of community effort on particular projects. Alyuen ran as an outpost of Pmara Jutunta, also experiencing bursts of activity around projects.

\section{Job Network and continuing CDEP under Central Desert Shire}

Another development during 2007 was that a Job Network provider, the Tangentyere Job Shop, established an office in Ti Tree. CDEP participants were now being encouraged to register with a Job Network provider and, if they did, there were funds available to support their activities, including in CDEP. My interactions with Tangentyere Job Shop suggested that, in comparison with elsewhere, ACGC did not 
greatly draw on their resources. This was probably because ACGC was having trouble filling its $150 \mathrm{CDEP}$ places and had plenty of funds to spend on CDEP participants from internal resources. Tangentyere Job Shop dealt with the jobseekers in the Anmatjere region largely independently of ACGC and its CDEP, which led to a slight sense of competition and tension between the two organisations rather than close cooperation.

Two larger significant developments that were occurring during 2007 and 2008 were the closures of some nearby CDEPs, as a result of the Australian Government's emergency Intervention into Northern Territory Aboriginal communities, and the shires reform within Territory local government. In central Australia, closures of CDEPs from September 2007 started south of Alice Springs and had not reached Anmatjere by the time they were abandoned on the election of the Rudd Labor Government in November (see Chapter 2). ACGC was thus spared the trauma of closing its CDEPs and then being given the opportunity to reopen them some months later, as occurred further south (see Kennedy 2013: Chapter 3). But ACGC's CDEPs did still have to negotiate the transition to Central Desert Shire in mid-2008.

With the emergence of Central Desert Shire, the Anmatjere CDEPs were merged with one at Atitjere in the east and four in Warlpiri country to the west. The new Shire had over 300 CDEP participants operating out of all nine of its service centres across four wards (see Fig. 6.4). The Shire's main administrative office was established in Alice Springs, $100 \mathrm{~km}$ south of its southern boundary. For Engawala and Laramba, this felt like they had been given back a more independent settlement status as they no longer had to answer to an office in Ti Tree. Around Ti Tree, the coming of the Shire led to less consciousness of the distinction between the Nturiya and Pmara Jutunta CDEPs. These became seen as part of one CDEP around the Shire's Ti Tree service centre, as too did Wilora when in 2009 it was transferred from the Barkly CDEP to Central Desert Shire. The new Shire developed a central CDEP administration in Alice Springs, but understood that the CDEPs around its nine service centres could sometimes look quite different, both because of their histories and due to current staff capabilities. Central Desert Shire, like ACGC before it, proved a quite sensitive 'federal' administrator of CDEP and other programs. However, it did not have ACGC's fine-grained geographic sensitivity to differences in CDEPs within the centre of the Anmatjere 
region around Ti Tree (Sanders 2008a). This can be seen in Fig. 6.5, which shows the Pmara Jutunta CDEP men's shed labelled by Central Desert Shire as part of Ti Tree CDEP.

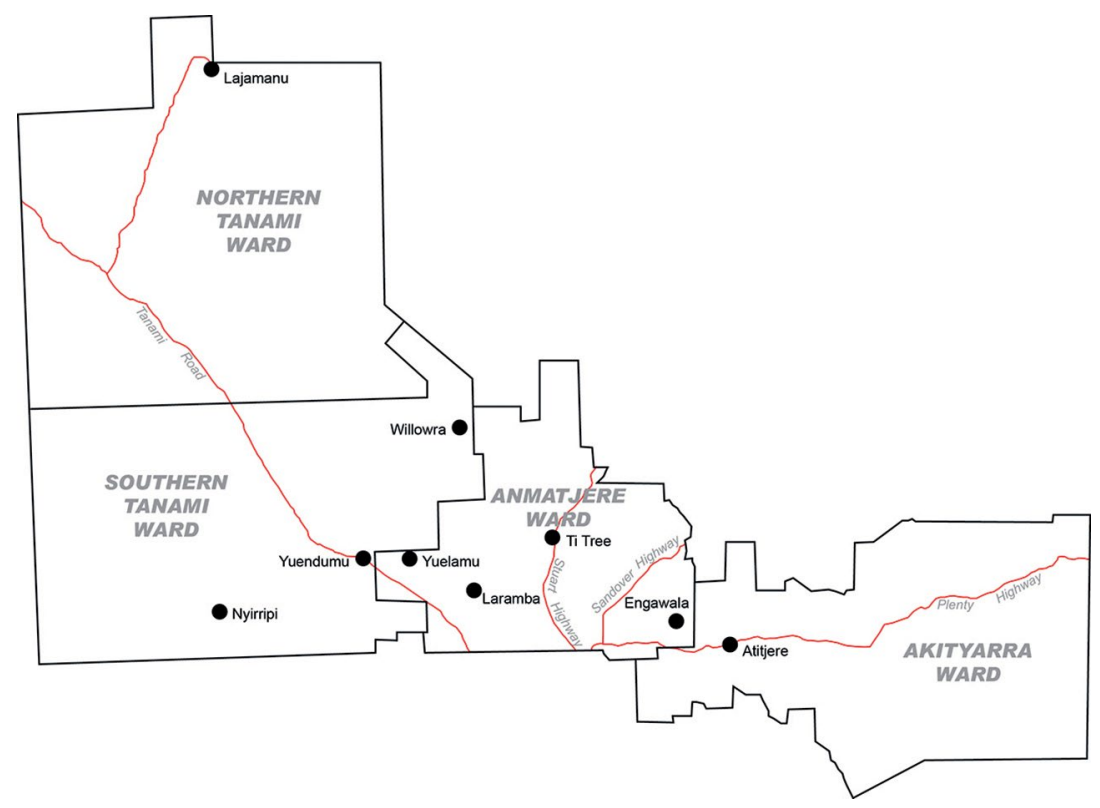

Fig. 6.4 Four wards and nine service centres of Central Desert Shire

Sources: Map supplied by Central Desert Shire and modified by John Hughes, CAEPR ANU.

In 2009, Central Desert Shire was successful in winning a new three-year contract for the provision of CDEP around all nine of its service centres. With the changes in CDEP policy from July 2009 (see Chapter 2), the Shire began acquiring CDEP participants who were social security income support recipients, alongside those remaining on wages as Shire employees. Managing these two different groups of CDEP participants was not always easy and the reaction of Central Desert Shire (unlike some other providers) was to let the number of wages-based CDEP participants lessen over time by natural attrition. By 2011, the Shire had less than 100 wages-based CDEP participants and the number was continuing to decrease. On-cost support resources for CDEP participants were, by contrast, expanding during this period. There was plenty of money available for equipment to support activities and even for more substantial infrastructure, like new activities centres. The range of activities that CDEP participants could undertake was, however, slightly more restricted than in 
previous years. This partly reflected a new policy of pushing the funding of service-type jobs out of CDEP onto other government departments, like night patrol to the Attorney-General's department and rangers to the Environment department. Restriction also reflected a policy push away from seeing art production as a legitimate CDEP activity, except for skills development without commercial sales.

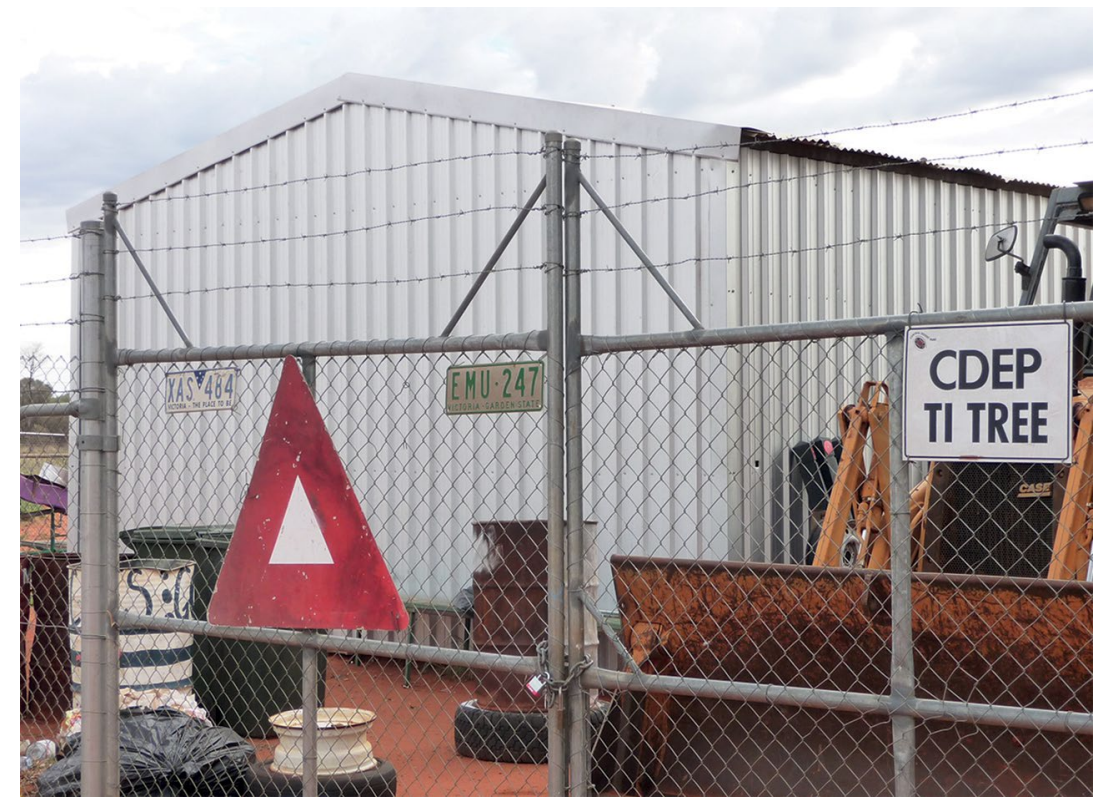

Fig. 6.5 CDEP men's shed at Pmara Jutunta with Central Desert Shire sign

Source: Photograph taken by author.

On my assessment, Central Desert Shire did quite a good job of navigating the changing policy landscape of CDEP during the years 2009 to 2012. While their number of wages-based CDEP participants decreased dramatically, their total number of CDEP participants remained up over 250 and the Shire was good at bringing in support money for activities. New CDEP activities centres were applied for and built in many of the Shire service centres. These helped provide kitchens and classrooms in which women's CDEP teams, in particular, could undertake activities. Men's CDEP teams seemed to prefer sheds, equipment and outdoor activities, though they could occasionally be found in the classrooms and kitchens. CDEP's basic infrastructure 
of localised authority and work habits, four mornings per week, was well established and administered by Central Desert Shire across a dispersed array of settlements, as it had been previously by ACGC.

\section{From Job Services Australia and CDEP to RJCP}

One of the other developments in the 2009-12 contract triennium was that the Job Network became remodelled as Job Services Australia (JSA). Tangentyere Job Shop was not awarded the new contract in Anmatjere, but the new provider, Jobfind, moved into the same premises in Ti Tree, providing some minimal sense of continuity (see Fig. 6.6). As registration with a JSA became more common among CDEP participants receiving Newstart Allowance and among other unemployed in Anmatjere, it became clear to all these 'jobseekers' that JSAs had a very different mode of operation to CDEPs. JSAs required attendance at a meeting with a case manager about once a month, which focused on the development and maintenance of an individual participation plan. This was very different from the CDEP mode of operation, which had a strong sense of being undertaken in teams four mornings per week. The two modes of operation could coexist, if JSA meetings for CDEP participants were scheduled for the afternoon or if participants were given leave from CDEP activities to attend JSA meetings. Some of this did begin to occur during the 2009-12 contract triennium. But the parallel operation of CDEP and JSA also opened up questions about the relationships between these two very different processes. Did they constitute an unnecessary duplication of employment services or were they usefully complementary? Was one mode of operation seen as more valuable than the other or were they equally valued? As Figs 6.6 and 6.7 suggest, both programs in Anmatjere saw things as possible, but one focused on 'anything' and the other on 'everything'! CDEP's informal sign also suggested more localised authority. 
BETTER THAN WELFARE?

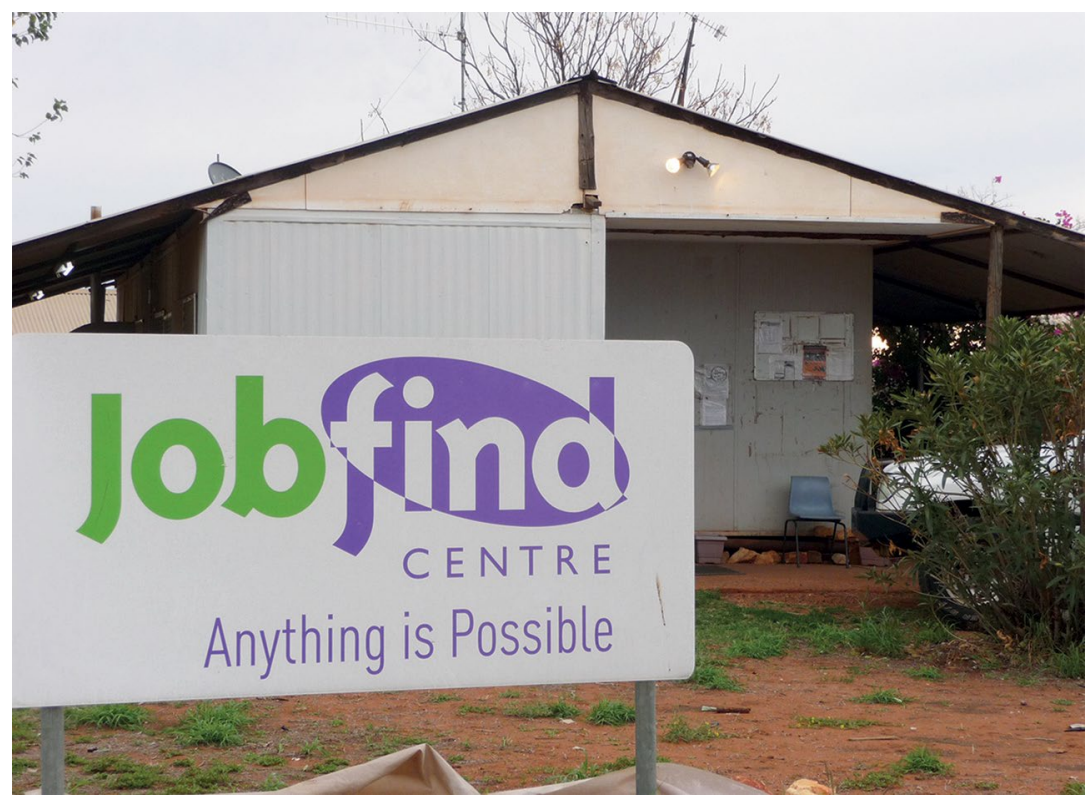

Fig. 6.6 Jobfind office in Ti Tree 2009-13

Source: Photograph taken by author.

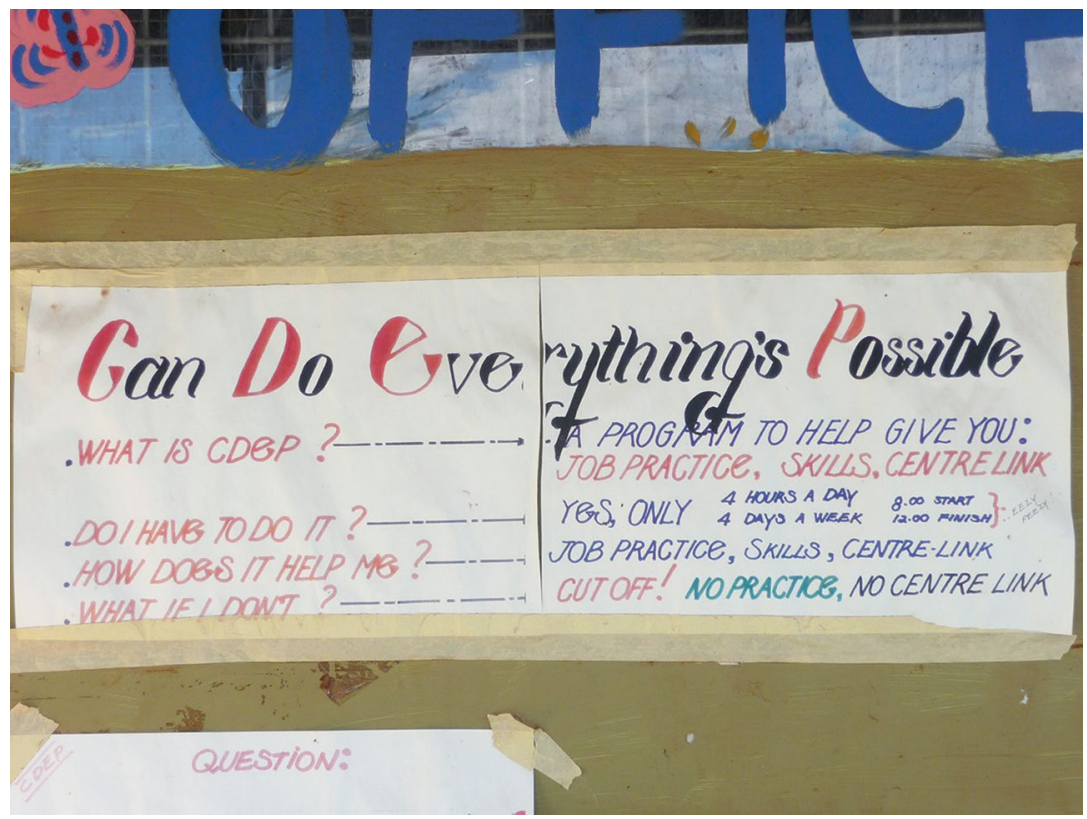

Fig. 6.7 Informal CDEP sign 2013

Source: Photograph taken by author. 
The Gillard Labor Government's review of 'remote participation and employment servicing' in late 2011 tended towards a negative view of the program 'arrangements' that already existed. The combination of JSA and CDEP, along with the Indigenous Employment Program and Disability Employment Services, was variously described as 'fragmented', 'confusing', 'inflexible and unresponsive' (Arbib et al. 2011: 7). The proposed new model of 'a single provider' in each region, subsuming all four previous programs, was promoted as 'simpler, more integrated and more flexible', as well as more 'tailored' to the 'diverse' communities of remote areas (Arbib et al. 2011: 8). This negative framing of the old was reinforced in May 2012, when it was anticipated that the new RJCP would be 'more integrated and flexible' and that the single provider would have a 'permanent presence' in the region, enabling it to provide more 'personalised support for job seekers' (Macklin et al. 2012a).

What was not said in this official analysis, but was clearly inevitable, was that there would be competition and rationalisation of CDEP and JSA providers in the year leading up to the commencement of RJCP in July 2013. The call for 'expressions of interest' in being an RJCP provider in October 2012 noted that 'interested organisations' could apply as 'individual providers or in partnership with other organisations'. It also noted that there was $\$ 15$ million available 'to help build the capacity of potential providers' and that the government wanted 'as many local Indigenous organisations delivering the new program as possible' (Macklin et al. 2012b).

Central Desert Shire was interested in becoming an RJCP provider largely because it foresaw that the new single provider program would have major implications for its constituents. As well as having experience running CDEP around all nine of its service centres, the Shire also had some limited experience running JSA, in conjunction with Job Futures, around its eastern service centre at Atitjere (see Fig. 6.4). The Shire thus had experience in both major preceding programs and would be a credible RJCP applicant, but there were also a couple of problems. One was that the Shire boundaries did not correspond with those of RJCP regions. RJCP region 25 fell in the centre of the Shire in its Anmatjere and Southern Tanami wards. However, around its edges the Shire was part of three more RJCP regions (see Figs 6.4 and 6.8 ). This related to a second problem, which was that, under its local 
government legislation, the Shire could not act outside its boundaries and had some restrictions on its ability to enter into partnerships with other organisations.

The Shire became an individual applicant for RJCP in region 25 and part of a partnership application in region 24 overlapping its eastern boundaries. The application was successful in region 25, but not in region 24. The Shire thus became an RJCP provider in 2013 around five of its service centres (Ti Tree, Laramba, Yuelamu, Yuendumu and Willowra), but not the other four (Atitjere, Engawala, Lajamanu and Nyirripi). In these latter areas, the Shire had to negotiate with the successful RJCP applicants for their access to former CDEP infrastructure and resources.

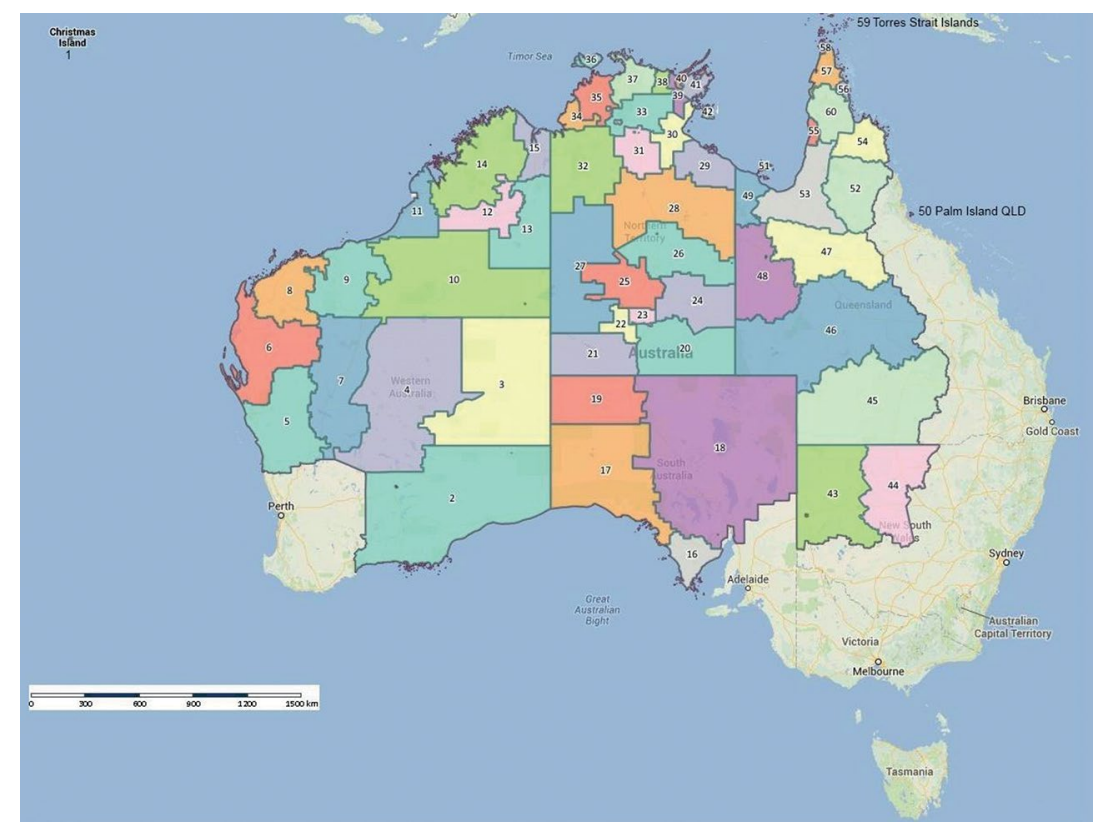

Fig. 6.8 Map of 60 RJCP regions

Source: Department of Employment, Education and Workplace Relations 2013.

The question that most intrigued me, as I observed the emerging transition to RJCP in Anmatjere, was how the two different modes of operation of CDEP and JSA would come together in this new single program? Would there be teams of participants undertaking activities on a daily and weekly basis or would case workers doing monthly interviews with individual jobseekers be the predominant 
mode of operation? In Anmatjere, it turned out to be the latter and my impression is that this has been the dominant pattern elsewhere as well, although not inevitably and invariably so. ${ }^{1}$ What possibly led Central Desert Shire in this direction was some embracing of the rhetoric of past policy and program failure.

While existing CDEP administrators were central to the Shire's bid for RJCP, there was also a sense that RJCP would not be a continuation of CDEP within Central Desert. Even before it was known in May 2013 that one of the Shire's bids for RJCP had been successful, it became apparent that there would be some quite significant changes in personnel and mode of operation. CDEP staff would have to apply for new jobs with new duty statements, which could be quite different from existing ones. CDEP staff started leaving in quite large numbers in early 2013, unsure that they would have a job by mid-year even if the Shire was successful in winning an RJCP provider contract. When I visited Laramba and the communities around Ti Tree in the early days of June 2013, CDEP had effectively already shut. Resignations and absences over the previous couple of months had reduced CDEP supervisory staff to one person in Laramba and one based in Ti Tree covering both the Pmara Jutunta and Nturiya offices. The women's CDEP teams in these places had ceased to operate a month or more before and the men's teams were reduced to a few individuals hanging around the shed. The two remaining supervisory staff were 'outdoor' workers who could not see themselves being applicants for the RJCP case manager 'office' jobs that were being advertised at the time of my visit. So they too were uncertain about their future employment.

In many ways, the senior management at Central Desert Shire had little choice but to employ new people to get RJCP up and running in mid2013. The contract was based on an Employment department model of registering individual jobseekers, meeting with them monthly and developing individual participation plans in return for the provider organisation receiving a basic service fee. While there were aspirations to have activities for jobseekers, and resources that could be drawn on for this purpose, the more basic task was the office job of

1 This impression comes from working with $\mathrm{PhD}$ student Lisa Fowkes on an Australian Research Council Linkage Project (LP130100226) with Jobs Australia as contributing Industry Partner, entitled Implementing the Remote Jobs and Communities Program: How is policy working in Indigenous communities? 
getting individuals entered in the computer system and meeting basic requirements so that the service fees to the provider could start flowing. This was more the style of expertise that came from JSA operations than from CDEP. While Central Desert Shire had some experience with JSA, this was probably not enough. The Shire needed new staff who could do this computer-based case management work. The expertise of CDEP staff was more collaborative and activity-based, which would be good in the longer term, but was not the immediate priority. But Central Desert Shire also, to some extent, accepted the predominant rhetoric that CDEP had been a failure and needed to be left behind.

During the latter months of 2013, as RJCP was transferred administratively into the Department of the Prime Minister and Cabinet (see Chapter 2), I observed Central Desert Shire and its constituents continuing to struggle with RJCP. Former CDEP participants were perplexed by the monthly meetings, intended to develop individualised participation plans but without much activity in between. Compared to their former four mornings per week work habit in localised teams, this monthly individual check-in regime seemed empty, as if something had been taken from them, as indeed it had. Around Ti Tree, there was the added complication that RJCP was not physically reaching out to the outlying communities of Pmara Jutunta and Nturiya. The new activity centre and RJCP office, built in the last year of CDEP but never used, was in Ti Tree town (see Fig. 6.9). This required transport in from the communities where most people lived. On occasions I saw quite angry exchanges between RJCP case managers and former CDEP participants who came to their monthly meetings from very different perspectives and past experiences.

During 2014, Central Desert's administration of RJCP did begin to include activities, as well as case management. The September 2014 edition of Central Desert News included two stories about RJCP, one about an arts activity in the 'old Op Shop' at Yuelamu, which had produced a large painting being 'donated to the new council building', and the other about a team of RJCP men who had helped lay $18 \mathrm{~km}$ of pipe to 'deliver drinking water to Alyuen'. When I visited Ti Tree in October 2014, there were two activities supervisors working alongside the case manager focused on office work. When they said they were having trouble getting RJCP participants to come into town for activities, I suggested reopening the men's shed at Pmara Jutunta. The reaction was immediate. At 8am the next day, when the 
supervisors opened the gates of the yard around the Pmara Jutunta shed, no less than 8 to 10 men walked up from their houses ready for activities. Over 18 months since the shed last operated, the daily work habits of CDEP participants were easily reinvigorated.

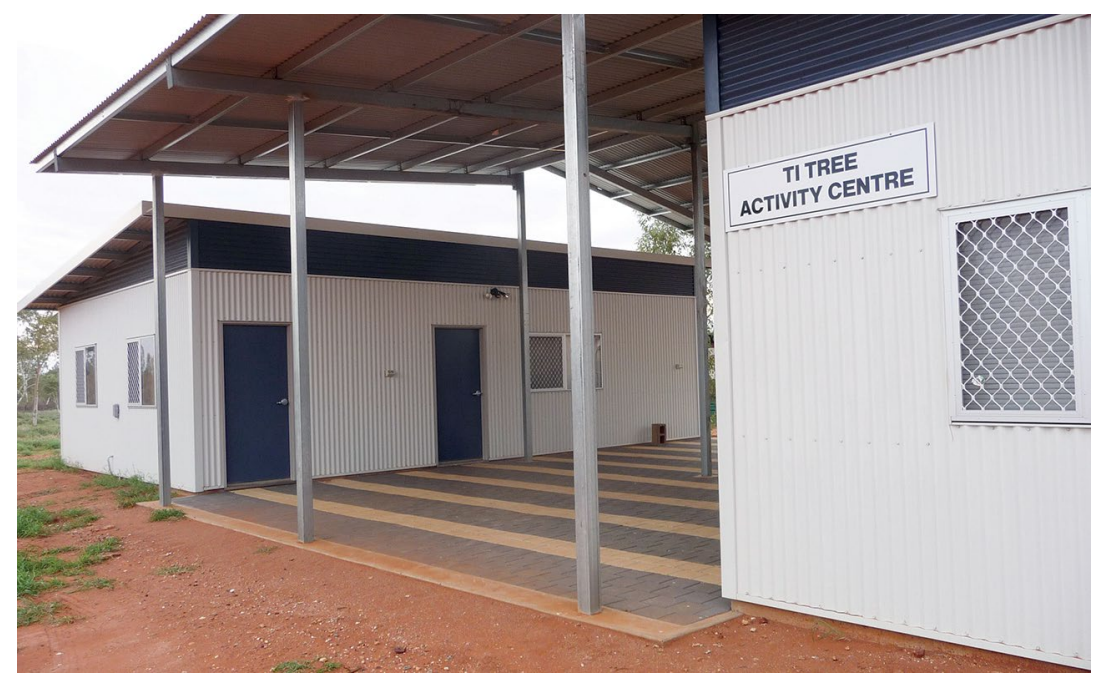

Fig. 6.9 New CDEP/RJCP Activity Centre and Office in Ti Tree 2013

Source: Photograph taken by author.

I did not visit Anmatjere in 2015, so I cannot say with any authority how RJCP is progressing. I suspect that monthly meetings and individual case management are still predominating and possibly always will due to the structure of the employment services contract. However, I am also conscious that, under the Department of the Prime Minister and Cabinet and the Abbott Coalition Government, the funding agreements and compliance frameworks for RJCP were significantly reworked to emphasise activities. I will leave analysis of these changes to future observation and writing. But in conclusion I wish to turn more explicitly to an argument about practice and its relationship to policy and program review. 


\section{Maintaining good practice: A first rule of policy and program review}

Public policy is by nature aspirational. It constructs existing social and economic circumstances as in some way deficient and problematic and then tries to improve them. As the great American social scientist Charles Lindblom (1990) put it in the subtitle of his book Inquiry and Change, this 'attempt to understand and shape society' is often 'troubled', achieving less than is hoped. When policies and programs are seen as not achieving high hopes, it is understandable that they become analysed as failures, and new policies and programs are suggested to replace them. However, there is a downside to this wellintentioned dynamic, which may indeed have been what predominated when the Gillard Labor Government reviewed 'remote participation and employment servicing' in 2011 and decided that CDEP and JSA were 'fragmented'. Another more positive analysis, hinted at above, might have pointed to the two very different modes of operation of these programs and suggested that they were usefully complementary. But this was not to be. The negative analysis of what already existed prevailed easily and, before we knew it, existing good practice was being thrown out in the process of introducing a single new program to replace the existing four.

To some extent, Central Desert Shire embraced the idea of past policy and program failure and tried to build something new in RJCP. The unexpected outcome was that the Shire lost what it already had in CDEP and, two years on, was still trying to rebuild. I am aware of a handful of RJCP providers across the 60 regions who did not accept this 'failure and change' style of analysis. These providers deliberately tried to maintain through RJCP good practice already established under CDEP (and to lesser extent JSA). ${ }^{2}$ This required some strategic alliance building between the skill sets of JSA and CDEP, as the RJCP contract clearly required JSA-type skills. However, maintenance of existing good practice also required some self-conscious holding of a line against the reframing of CDEP as a 'failure' and 'passive welfare' (see Chapter 2). Organisations that had long and deep involvement in wages-based CDEP knew that it was 'better than welfare' in a number of significant ways that were worth 
preserving, even against the prevailing rhetoric and analysis of the change to RJCP. Having only administered CDEP since 2008, alongside its local government functions, Central Desert Shire did not have a deep enough understanding of how it could and would have to hold this line against reframing in order to maintain good existing practice.

Previously I have written about how the 'failure and change' style of analysis became dominant in Australian Indigenous affairs during the fourth term of the Howard Coalition Government from 2004 to 2007, producing a 'generational revolution' of policy and institutional redesign (Sanders 2008b). While ostensibly pushing back against this style (with the apology to the stolen generations and stopping the immediate abolition of CDEP in the Northern Territory), on balance the Rudd Labor Government continued the generational policy revolution in Australian Indigenous affairs (Hunt \& Sanders 2010). The Gillard Government's review of 'remote participation and employment servicing' and its combining of CDEP and JSA into RJCP can also be seen as a continuation of this style of analysis leading to major institutional change. Once a 'failure and change' discourse is established as dominant, it can itself be hard to change. Maintaining good existing practice, like the work habits and localised authority of CDEP, can become very hard amidst the constant policy and program reviews of a long-running generational revolution. But if we are analytically self-aware of the downside of policy and program review, we may at least have some prospect of maintaining good practice. The good practice work habits of the CDEP men at Pmara Jutunta were able to be reinvigorated after 18 months of shut gates at their shed. So existing good practice can survive the aspirations of policy review and the downsides of program change, but only if maintaining good practice becomes a self-conscious rule of policy review. This is the precautionary principle of 'first do no harm' in another guise.

\section{References}

Arbib M, Macklin J \& Ellis K (2011). The future of remote participation and employment servicing arrangements: discussion paper, Minister for Indigenous Employment and Economic Development, Minister for Families, Housing Community Services and Indigenous Affairs, Minister for Employment Participation and Childcare, Australian Government, Canberra. 
Hunt J \& Sanders W (2010). Sorry, but the Indigenous affairs revolution continues. In Aulich C \& Evans $\mathrm{M}$ (eds), The Rudd Government: Australian Commonwealth administration 2007-2010, ANU E Press, Canberra.

Kennedy A (2013). Values, voice and choice: Western Arrernte outstation engagement in the Northern Territory intervention, $\mathrm{PhD}$ thesis, Southern Cross University, Lismore, New South Wales.

Lindblom C (1990). Inquiry and change: the troubled attempt to understand and shape society, Yale University Press, New Haven.

Macklin J, Shorten B \& Collins J (2012a). Remote Jobs and Communities Program: jobs and stronger communities for people in remote Australia, Minister for Families, Community Services and Indigenous Affairs, Minister for Employment and Workplace Relations, Minister for Indigenous Employment and Economic Development, Australian Government, Canberra.

Macklin J, Shorten B \& Collins J (2012b). Call for providers to deliver new $\$ 1.5 b$ remote jobs program, media release, Minister for Families, Community Services and Indigenous Affairs, Minister for Employment and Workplace Relations, Minister for Indigenous Employment and Economic Development, Australian Government, 2 October 2012, Canberra.

Sanders W (2008a). Regionalism that respects localism: the Anmatjere Community Government Council and beyond. In Hunt J, Smith D, Garling S \& Sanders W (eds), Contested governance: culture, power and institutions in Indigenous Australia, CAEPR Research Monograph No. 29, ANU E Press, Canberra, 283-309.

Sanders W (2008b). In the name of failure: A generational revolution in Indigenous affairs. In Aulich C \& Wettenhall R (eds), Howard's fourth government: Australian Commonwealth Administration 2004-2007, UNSW Press, Sydney: 187-206. 
This text is taken from Better Than Welfare?: Work and livelihoods for Indigenous Australians after CDEP, edited Kirrily Jordan, published 2016 by ANU Press, The Australian National University, Canberra, Australia. 